\begin{tabular}{|c|c|c|c|c|c|}
\hline $\begin{array}{l}\text { Case } \\
\text { No }\end{array}$ & $\begin{array}{c}\text { Duration } \\
\text { of } \\
\text { treatment } \\
\text { (years) }\end{array}$ & $\begin{array}{l}\text { Interval between } \\
\text { insertion of } \\
\text { penultimate and } \\
\text { last implants } \\
\text { (months) }\end{array}$ & $\begin{array}{l}\text { Type of implant } \\
\text { last inserted }\end{array}$ & $\begin{array}{l}\text { Interval between } \\
\text { insertion of } \\
\text { last implant } \\
\text { and recurrence } \\
\text { (weeks) }\end{array}$ & $\begin{array}{c}\text { Oestradiol } \\
\text { when } \\
\text { symptoms } \\
\text { recurred } \\
(\mathrm{pmol} / \mathrm{l})\end{array}$ \\
\hline 1 & $2 \cdot 5$ & 3 & Oestradiol $75 \mathrm{mg}$, testosterone $50 \mathrm{mg}$ & 9 & 2325 \\
\hline 2 & 3 & 3 & Oestradiol $75 \mathrm{mg}$ & 12 & 2000 \\
\hline 3 & 7 & 4 & Oestradiol $50 \mathrm{mg}$, testosterone $100 \mathrm{mg}$ & 3 & 1500 \\
\hline 4 & 3 & 2 & Oestradiol $200 \mathrm{mg}$ & $<4$ & 2995 \\
\hline 5 & 0.75 & 4 & Oestradiol $50 \mathrm{mg}$, testosterone $100 \mathrm{mg}$ & 8 & 2400 \\
\hline 6 & 2 & $2 \cdot 5$ & Oestradiol $50 \mathrm{mg}$, testosterone $100 \mathrm{mg}$ & $<4$ & 1450 \\
\hline 7 & 4 & 4 & Oestradiol $100 \mathrm{mg}$, testosterone $100 \mathrm{mg}$ & 12 & 2500 \\
\hline 8 & 7 & 4 & Oestradiol $100 \mathrm{mg}$, testosterone $100 \mathrm{mg}$ & 16 & 1600 \\
\hline 9 & 7 & 7 & Oestradiol $100 \mathrm{mg}$ & $<4$ & $>3500$ \\
\hline 10 & 7 & 5 & Oestradiol $50 \mathrm{mg}$, testosterone $100 \mathrm{mg}$ & 16 & 1900 \\
\hline 11 & 5 & 4 & Oestradiol $100 \mathrm{mg}$ & 6 & 1800 \\
\hline 12 & 3 & 3 & Oestradiol $75 \mathrm{mg}$, testosterone $100 \mathrm{mg}$ & 6 & 1865 \\
\hline
\end{tabular}

doctor into inserting higher doses more frequently because symptoms recurred early.

The table shows the total duration of treatment, the interval between insertion of the penultimate and last implants, the type of implant last inserted, the interval between insertion of the last implant and recurrence of symptoms, and the plasma oestradiol concentrations when symptoms recurred.

\title{
Comment
}

Troublesome symptoms of oestrogen deficiency (flushes, sweats, mood swings, and irritability) in patients with supraphysiological plasma oestradiol concentrations (above $1200 \mathrm{pmol} / \mathrm{l}$, the periovulatory peak) have not been reported previously. We suspect that this phenomenon is a form of tachyphylaxis, with successive implants relieving symptoms for ever diminishing periods. The mechanism of action is unknown. In adult lower mammals supraphysiological oestradiol concentrations cause major functional changes, possibly due to perineuronal gliosis and glial thickening within the hypothalamus'; similar

\section{Effect of rate of infusion of quinine on insulin and glucose responses in Malawian children with falciparum malaria}

Department of Tropical Diseases, Liverpool School of Tropical Medicine, Liverpool L3 50A

Malcolm E Molyneux, FRCP, senior lecturer

Gregory Harper, BSC,

laboratory technician

Department of Community Health Science, College of Osteopathic Medicine, Michigan State University, Michigan, United States

Terrie E Taylor, Do, assistant professor

Kamuzu Central Hospital, Lilongwe, Malawi Jack J Wirima, MRCP, principal medical specialist

Correspondence to: Dr Molyneux.

BrMed f 1989;299:602-3 anatomical changes that disturb function in the vasomotor centre might occur in postmenopausal women.

Irrespective of the mechanism, the clinical importance of these data is clear: doctors should not rely solely on the recurrence of symptoms to time reimplantation. Some of our patients (cases 1, 2, 4, 12) received implants too frequently (after three months or less). Other patients treated with implants of only $50 \mathrm{mg}$ oestradiol (for example, case 5) received a new implant when symptoms recurred every four months, and yet plasma oestradiol concentrations of $2400 \mathrm{pmol} / \mathrm{l}$ were eventually achieved. Because of these and previous reports of accumulation ${ }^{4}$ we wonder whether plasma oestradiol concentrations should be measured routinely before reimplantation if there is any risk of accumulation.

Optimal management in the cases described here is not known. There are no data to indicate that supraphysiological oestradiol concentrations cause harm. We suspect, however, that further implantation relieves symptoms for ever shorter periods. Our approach has been to withhold all forms of oestrogen until the plasma oestradiol concentration has returned to less than $200 \mathrm{pmol} / \mathrm{l}$. This may take many months, during which the patients suffer intense vasomotor and psychological symptoms, are miserable, and need much support. We then start giving oestrogens in a form that does not cause accumulation.

1 Greenblatt RB, Suran RR. Indications for hormone pellets in the therapy of endocrine and gynecological disorders. Am J Obstet Gynecol 1949;57:294

2 Savvas M, Studd JWW, Fogelman I, et al. Skeletal effects of oral oestrogen compared with subcutaneous oestrogen and testosterone in postmenopausal women. Br Med f 1988;297:331.

3 Thom MH, Collins WP, Studd JWW. Hormonal profiles in postmenopausal women after therapy with subcutaneous implants. Br $f$ Obstet Gynaecol 1981;88:426

4 Barlow DH, Abdalla HI, Roberts AD, et al. Long term hormone implant therapy-hormonal and clinical effects. Obstet Gynecol 1986;67:321.

5 Naftolin F, MacLusky NJ, Lerantyl CZ, et al. The cellular effects of estrogen on neuroendocrine tissues. I Steroid Biochem 1988;29:215-28.

(Accepted l6 May 1989)

phase radioimmunoassay), and quinine (by high performance liquid chromatography) concentrations at zero, one, and three hours after the start of the first infusion of quinine dihydrochloride, which was given intravenously according to the following three regimens: nine patients received $10 \mathrm{mg} / \mathrm{kg}$ infused over three hours (group 1); 10 received $20 \mathrm{mg} / \mathrm{kg}$ infused over three hours (group 2); and 10 received $10 \mathrm{mg} / \mathrm{kg}$ infused over one hour (group 3). Quinine was given in $5 \%(50 \mathrm{~g} / \mathrm{l})$ glucose in half strength Darrow's solution at $80 \mathrm{ml} / \mathrm{kg} / 24 \mathrm{~h}$ in all groups.

The patients in group 2 had a significantly lower mean packed cell volume than those in groups 1 and 3 ( 0.19 compared with 0.29 and 0.32 respectively). There were no significant differences among the three groups in any other variables, including age, duration or pattern of symptoms, physical signs, and additional treatment. At the end of the first hour of treatment the mean (SD) plasma quinine concentrations were $4 \cdot 6$ $(2 \cdot 4), 10 \cdot 1(2 \cdot 4)$, and $13 \cdot 0(3 \cdot 1) \mathrm{mg} / \mathrm{l}$ in groups 1,2 , and 3 , respectively $(\mathrm{F}=20 \cdot 1 ; \mathrm{df}=2,21 ; \mathrm{p}<0.0001$ by analysis of variance). At three hours they were $10 \cdot 1(3 \cdot 4), 17 \cdot 4(3 \cdot 1)$, and $10 \cdot 3(3 \cdot 3) \mathrm{mg} / \mathrm{l}(\mathrm{F}=16 \cdot 9$; $\mathrm{df}=2,24 ; \mathrm{p}<0 \cdot 001)$.

The mean plasma glucose concentration increased slightly but not significantly in each group during observation. None of the patients became hypoglycaemic during the treatment. At the end of the first hour of infusion the mean plasma insulin concentration had risen from $7 \cdot 4(5 \cdot 2)$ to $16 \cdot 6(10 \cdot 9) \mathrm{mU} / \mathrm{l}$ in group 1 , from $5 \cdot 0(3 \cdot 9)$ to $14 \cdot 1(15 \cdot 3) \mathrm{mU} / 1$ in group 2 , and from $8 \cdot 2(4 \cdot 6)$ to $35 \cdot 5(21 \cdot 1) \mathrm{mU} / \mathrm{l}$ in group $3(\mathrm{~F}=3.93$; $\mathrm{df}=2,23 ; \mathrm{p}<0.05$ by analysis of covariance). At three symptoms was identified. ${ }^{2}$ All were normoglycaemic (glucose concentration $>2 \cdot 2 \mathrm{mmol} / \mathrm{l}$ ) at admission.

We measured their plasma glucose (by the glucose oxidase method with an autoanalyser), insulin (by solid 

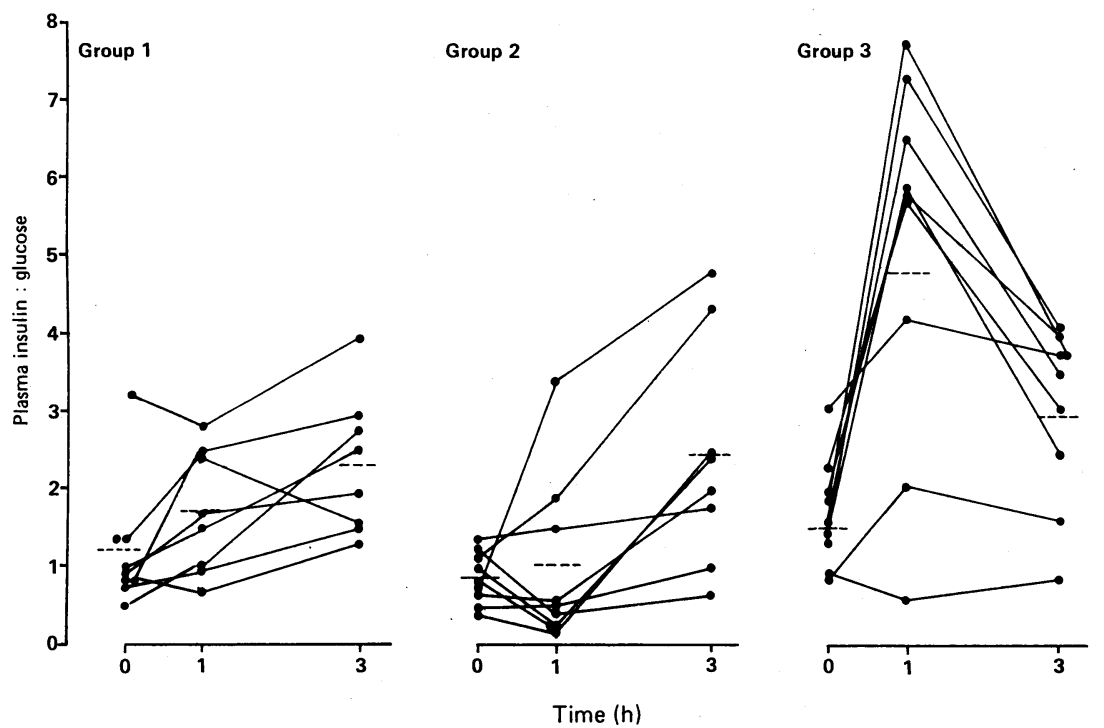

Ratios of plasma insulin to plasma glucose concentrations before and one and three hours after start of intravenous infusion of quinine in three groups of Malawian children with falciparum malaria. Dotted lines indicate mean values

hours insulin concentrations were similar in all groups $(19.8(11.6), 14.7(8.4)$, and $16.2(8.9) \mathrm{mU} / 1(\mathrm{~F}=0.61$; $\mathrm{df}=2,24 ; \mathrm{p}>0 \cdot 5)$ ).

Changes in the ratio of insulin to-glucose concentration from baseline values in the three groups (figure) were similar to changes in plasma insulin concentration. The increase in the ratio differed significantly among the groups at one hour $(F=6 \cdot 18 ; \mathrm{df}=2,23$; $\mathrm{p}<0: 01$ ), being greatest in group 3 . The increase at three hours was similar for all groups. Plasma quinine concentrations at one hour correlated significantly with the increases in both plasma insulin concentration $(\mathrm{r}=0.550, \mathrm{n}=28, \mathrm{p}<0.01)$ and the ratio of insulin to glucose concentration $(\mathrm{r}=0.548, \mathrm{n}=23, \mathrm{p}<0.01)$ during the first hour of treatment in all patients.

\section{Release of atrial natriuretic factor after pericardiocentesis for malignant pericardial effusion}

\author{
D B Northridge, J McMurray, S Ray, \\ A Jardine, H J Dargie
}

Department of Cardiology,

Western Infirmary,

Glasgow G11 6NT

D B Northridge, MRCP,

British Heart Foundation junior research fellow

J McMurray, MRCP, registrar in cardiology

S Ray, MRCP, research registrar in cardiology

H J Dargie, FRCP,

consultant cardiologist

MRC Blood Pressure Unit, Western Infirmary,

Glasgow G11 6NT

A Jardine, MRCP, registrar in medicine

Correspondence to: $\mathrm{Dr}$

Northridge.

BrMed f 1989;299:603-4

\section{Commen}

The hypoglycaemic effect of quinine was first noted by Hughes, who suggested that quinine stimulates secretion of insulin by the pancreas. ${ }^{3}$ Various rates of infusion have been recommended for treating malaria. When given over three hours in a constant infusion of $5 \%$ glucose quinine did not cause hypoglycaemia in 76 Malawian children with cerebral malaria, ${ }^{4}$ but four of nine Zairean children given one hour infusions developed hypoglycaemia (plasma glucose concentration $<2.8 \mathrm{mmol} / \mathrm{l}$ ).

The results of the present study suggest that the rate of infusion of quinine is an important determinant of the secretion of insulin that is induced by the drug and that a one hour infusion may lead to higher insulin concentrations and a greater risk of hypoglycaemia than a slower infusion.

We thank the Ministry of Health of Malawi and the senior medical superintendent of the Queen Elizabeth Central Hospital for permission to carry out these studies; the medical and nursing staff of the department of paediatrics for their cooperation; and Dr Alex Fletcher, Dean Myron Magen, and Professor Marcel Hommel for their support. The work was supported by the Burroughs-Wellcome Fund, the World Health Organisation's special programme for research and training in tropical diseases, and the United States National Institutes of Health.

1 White NJ, Warrell DA, Chanthavanich P, et al. Severe hypoglycemia and hyperinsulinemia in falciparum malaria. $N$ Engl $\mathcal{F}$ Med 1983;309:61-6.

2 Molyneux ME, Taylor TE, Wirima JJ, Borgstein A. Clinical features and prognostic indicators in paediatric cerebral malaria: a study of 131 comatose prognostic indicators in paediatric cerebral ma

3 Hughes TA. Effects of quinine on the sugar of the blood. Indian 7 Med Res 1925;13:321-36.

4 Taylor TE, Molyneux ME, Wirima JJ, Fletcher KA, Morris K. Blood glucose levels in Malawian children before and during the administration of intravenous quinine for severe falciparum malaria. $N \mathrm{Engl}$ f Mied 1988;319: 1040-7.

5 Okitolonda W, Delacollette C, Malengreau M, Henquin JC. High incidence of hypoglycaemia in African patients treated with intravenous quinine for severe malaria. $\mathrm{Br}$ Med f 1987;295:716-8.

(Accepted 8 fune 1989)

breast ( 2 patients), and unknown ( 1 patient). All patients had a clinical diagnosis of cardiac tamponade confirmed by echocardiography. Blood samples were drawn for measuring the plasma atrial natriuretic factor concentration immediately before, 30 minutes after, and 180 minutes after pericardiocentesis. Samples were collected in chilled tubes containing edetic acid and aprotinin, and plasma was immediately separated by centrifugation at $4^{\circ} \mathrm{C}$ and assayed for atrial natriuretic factor by radioimmunoassay after extraction in Sep-pak cartridges ${ }^{2}$ (reference range 2-17 $\mathrm{pmol} / \mathrm{l})$. Significance levels were determined by Student's paired $t$ test.

The mean volume (range) of fluid removed at pericardiocentesis was 725 (400-1100) ml. Plasma atrial natriuretic factor (mean and SD) was slightly raised at baseline before pericardiocentesis, at $19 \cdot 2$ $(7 \cdot 1) \mathrm{pmol} / 1$ (figure). There was a further rise to $30 \cdot 3$ $(7 \cdot 7) \mathrm{pmol} / 1(\mathrm{p}<0.05) 30$ minutes after and to 36.7 $(11.9) \mathrm{pmol} / \mathrm{l}(\mathrm{p}<0.005) 180$ minutes after pericardiocentesis. The mean rise in plasma atrial natriuretic factor concentration at 180 minutes was $17.5 \mathrm{pmol} / \mathrm{l}$, ( $95 \%$ confidence interval $9 \cdot 7$ to $25 \cdot 3 \mathrm{pmol} / \mathrm{l}$ ). All patients improved clinically, with a rise in arterial blood pressure, a fall in jugular venous pressure, and diuresis.

\section{Comment}

This is the first report of plasma atrial natriuretic factor concentrations in a series of patients with cardiac tamponade of malignant aetiology. We found that peptide levels rise after pericardiocentesis.
Six patients (three men) with malignant pericardial effusion were studied before and after pericardiocentesis. The mean age (range) was 57 (37-74) years The primary site of malignancy was lung ( 3 patients), 